\title{
INFLATION: LIMITS OF SLOWDAWN ${ }^{1}$
}

\author{
A.Bozhechkova, E.Goryunov, P.Trunin
}

In Q1 2016, inflation slowed down both month-on-month and year-on-year, driven by further decline in internal demand amid a strengthening rouble, as well as due to the high base effect a year earlier. However, expectations for high inflation are still strong, which will stem decline in price growth rates in the mid-run. ${ }^{1}$

In Q1 2016, inflation slowed down from $1 \%$ as of January month-end to $0.6 \%$ in February and to $0.5 \%$ in March. The annualized consumer price growth rate (over the same period of 2015) fell from $9.8 \%$ in January to $7.3 \%$ in March 2016 (Fig. 1). The annual growth rate of consumer prices slowed down rapidly largely due to the high base effect. The decline in consumer price growth rates in the Russian economy was primarily determined by a decline in internal

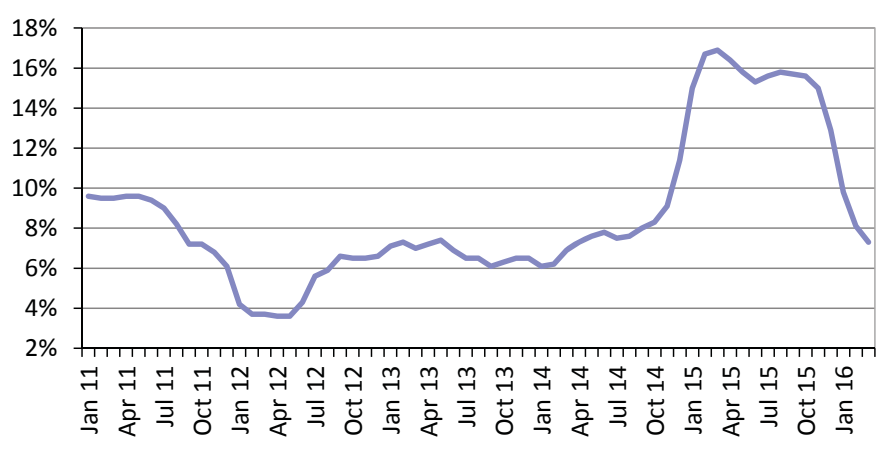

Source: Rosstat.

Fig. 1. CPI growth rate in 2011-2016 (\% change, year-over-year) demand and hence by companies' efforts to minimize their costs. For instance, negative growth rates of the producer price index have been observed since November 2015, and they reached $-1.3 \%$ in January and $-1.5 \%$ in February 2016.

In January-March, food price growth rates were down from $1.3 \%$ in January to $0.7 \%$ in February and to $0.3 \%$ in March. Agricultural produce, eggs and sugar saw most of the decline. Note that inflation for this product group was driven down primarily by the rouble exchange rate that strengthened in February-March 2016. The product group 'red meat and poultry meat' has been facing deflation since October 2015 amid falling demand for meat and with consumers' refocusing on cheaper poultry meat.

In January-March 2016, food price growth rates remained high, increasing by $0.8 \%$ in March 2016. However, the rouble's appreciation was followed by considerably slower growth rates in prices of goods that are most sensitive to exchange rate trends, including electric and other household appliances, audio visual goods, as well as medicaments.

In January-March 2016, growth rates of prices and tariffs of paid services to individuals dropped for all the categories of services: from $1 \%$ to $0.3 \%$ in February and $0.1 \%$ in March. The dynamics of prices of outbound tourism services (down by $2.7 \%$ in March 2016) contributed most to the decline, due to a strengthening rouble.

1 This paper was originally published in Online Monitoring of Russia's Economic Outlook No.7(25). 
Inflation stopped declining in April: the Consumer Price Index (CPI) reached $0.4 \%$ within the first 18 days of April. CPI stood at $0.5 \%$ in April 2015. In other words, the annualized inflation rate may cease slowing down in April.

According to the estimates released by Russia's central bank, in March 2016 the median one-year ahead expected inflation rate stood at $14.7 \%$, down by 1 p.p. from the value seen in February. The expected inflation rate reached its peak value of $16.7 \%$ in January. However, expectations for high inflation are still strong.

With price growth rates slowing down in Russia earlier in 2016, some experts have made an assumption that deflation may be anticipated. In particular, Bank of America analyst David Honer ${ }^{1}$ believes that Russia is threatened by being caught in a deflation trap in the long term, and this will be facilitated by cuts on state budget expenditure, current account surplus and a strengthening rouble. Sociologists also note that individuals have changed their consumer behaviour ${ }^{2}$ that tends to limit their spending amid a challenging macroeconomic context. All the above-listed factors do deter consumer demand and growth of prices of imported goods, that is, they slow down inflation growth rates.

In fact, deflation is not an exotic phenomenon at all. Price deflation was seen in both developed countries (Japan in 1993-2015, Ireland in 2010-2011) and emerging economies (China in 1998-1999, Lithuania in 2002-2003). While prices may fall for many reasons, there are two types of deflation that can be distinguished. The first one can be seen in advanced economies with an extremely low aggregate demand as a result of collapse of overheated financial markets, in which case a deflation spiral may occur: falling prices lead to higher unemployment rates that in turn entail a new decline in aggregate demand and bring an extra downward pressure on prices. Japan is a classic illustration of a deflation crisis in progress: since the mid 1990s Japan has been struggling to get out of the deflation trap. The current conditions in the Russian economy could not lead to this type of deflation. The second type of deflation is typical of emerging markets with a fixed exchange rate regime. The money supply and inflation processes in such countries tend to be extremely reliant on capital flows and trade balance. With a fixed exchange rate, capital outflows and net export cuts tend to force the money supply to shrink and prices to grow (Argentina in the mid 1990s). It is unlikely that Russia will face this type of deflation, because the rouble exchange rate is nearly free-floating.

Russia may The deflation in Chile may be of interest for, because it occurred in the macroeconomic context similar to that in Russia. Chile's CPI dropped by $1.5 \%$ in 2009 . That episode is distinguished by the fact that, first, Chile's central bank adhered to an inflation targeting policy, including a free floating exchange rate; second, prices of exported resource-based commodities plummeted in 2008-2009, that accounted for about 50\% of Chile's total exports; third, capital inflows gave way to capital outflows at that period. Under these circumstances, Chile's trade balance fell, national currency depreciated and GDP declined. In an effort to deter the plunging exchange rate and inflation, Chile's central bank lifted the key rate up to $8.25 \%$ in the second half of 2008 ,

1 http://tass.ru/ekonomika/2727282

2 http://www.vedomosti.ru/economics/articles/2016/03/21/634351-naselenie-depressiyu; http://www.levada.ru/indikatory/sotsialno-ekonomicheskie-indikatory/ 
whereupon the national currency began to firm up. With rapid slowdown of inflation and the economic downturn of 2009, Chile's monetary authorities lowered gradually the key rate to $0.5 \%$ earlier in 2010 , and the money stock shrank by $5 \%$. The example shows that deflation may occur under conditions similar to those in Russia, and a plausible reason for this may be rapid diminution in demand amid tight monetary policy conditions.

However, the money stock growth rates in Russia have not been below

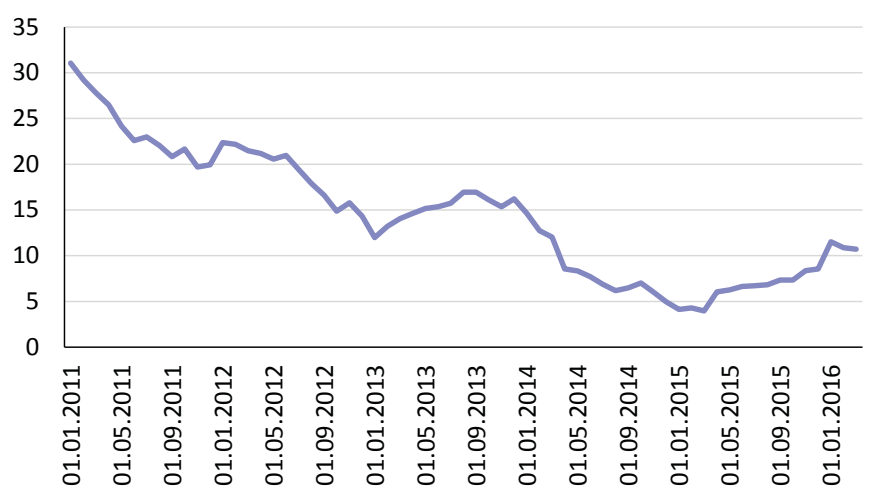

Source: Bank of Russia.

Fig. 2. Growth in seasonally adjusted money stock series (\% change, period on the same period previous year)

$4 \%$ since the start of 2010 , and now they are about $10 \%$ (Fig. 2). The international practice shows that the money stock growth per se cannot guarantee a positive inflation, because deflation may just as well be attended with growth in the money supply (Argentina in 1999-2000, Israel, Bulgaria in 2013-2014, Vietnam in 1996-2000). However, deflation used to follow a drastic slump in the money supply growth rates. Therefore, if the M2 growth rates are maintained at the current level, deflation is unlikely to occur. The money supply can shrink only if the Bank of Russia maintains high interest rates for too long, leaving them intact amid slowing down price growth rates. 